\title{
TINJAUAN HUKUM TERHADAP EKSEKUSI OBJEK JAMINAN FIDUSIA TANPA TITEL EKSEKUTORIAL YANG SAH
}

\author{
Khifni Kafa Rufaida dan Rian Sacipto \\ Fakultas Hukum dan Humaniora Universitas Ngudi Waluyo \\ Korespondensi: khifnikafarufaida@gmail.com
}

\begin{abstract}
Abstrak
Peristiwa penarikan oleh debt collector melahirkan asumsi publik yang bersifat subjektif dan tendensius, yang memojokkan posisi lembaga pembiayaan (kreditur). Padahal penarikan tersebut selalu diawali dengan somasi 3 (tiga) kali berturut-turut agar debitur segera melunasi prestasinya. Penarikan semacam ini sah dimata hukum, sebab konstruksi pembiayaan konsumen memiliki dua macam jaminan yaitu jaminan utama dan jaminan tambahan (jaminan fidusia). Jaminan yang kedua diperuntukkan sebagai jaminan kebendaan untuk memenuhi pelunasan seluruh hutang debitur. Titel eksekutorial dalam Sertifikat Jaminan Fidusia mempunyai kekuatan eksekutorial yang sama dengan putusan pengadilan yang telah memperoleh kekuatan hukum tetap meskipun tidak bersifat condemnatoir. Pemegang Sertifikat Jaminan Fidusia berkedudukan seperti seseorang yang sudah memegang putusan pengadilan yang telah mempunyai kekuatan hukum tetap. Namun, pelaksanaannya membutuhkan fiat eksekusi dari Ketua Pengadilan. Pendaftaran jaminan fidusia sangat penting karena melahirkan hak kebendaan yang memiliki sifat droit de suite, droit de preference, spesialitas dan publisitas.
\end{abstract}

Kata Kunci: Pendaftaran Fidusia; Titel Eksekutorial; Sertifikat Jaminan Fidusia.

\begin{abstract}
The retractions by the debt collector grow the subjective and tendentious public assumptions, which corner the financial institutions (creditors) position. Basically, the retraction always begins with a summons 3 (three) times so that the debtor immediately discharge his achievements. These retractions are legal in the eyes of the law since consumer financing construction has two kinds of guarantee namely main collateral and additional collateral (fiduciary collateral). The later guarantee is intended as a material security to meet the repayment of all debtors' debts. The executorial title in the Fiduciary Guarantee Certificate has the same executorial power as a court decision that has obtained permanent legal force even though it is not condemnatory. Holders of Fiduciary Guarantee Certificates as like someone who already holds court decisions that have permanent legal force. However, its implementation requires the fiat execution from the Chief of Justice. Fiduciary guarantee registration is very important because it grows the material rights which have the characteristics of droit de suite, droit de preference, specialties and publicity.
\end{abstract}

Keywords: Fiduciary Registration; Executorial Title; Fiduciary Guarantee Certificate. 


\section{PENDAHULUAN}

Unsur utama pemberian kredit adalah kepercayaan. Kepercayaan merupakan keyakinan kreditur bahwa penerima kredit (debitur) dapat memenuhi segala sesuatu yang telah disepakati di kemudian hari. Untuk memperoleh keyakinan dan kepercayaan tersebut harus sampai pada suatu keyakinan sejauh mana konsep penilaian kredit dapat terpenuhi dengan baik. ${ }^{1}$ Menurut Peraturan Presiden Nomor 9 Tahun 2009 tentang Lembaga Pembiayaan (selanjutnya disebut Perpres Lembaga Pembiayaan) adalah kegiatan pembiayaan untuk pengadaan barang berdasarkan kebutuhan konsumen dengan pembayaran secara angsuran.

Bank selaku lembaga pembiayaan wajib memperhatikan calon debitur dengan melakukan penilaian terhadap watak, kemampuan, modal, jaminan dan keadaan. Salah satu bentuk pengamanan kredit dengan perjanjian jaminan. Jaminan sebagai lembaga hukum melahirkan asas-asas hukum sebagaimana diatur dalam hukum perdata yang memiliki kedudukan penting dalam dunia ekonomi. ${ }^{2}$

Prinsip pada jaminan fidusia ialah constitutum possessorium, dimana objek fidusia tetap dikuasai pemberi fidusia. Artinya pemberi fidusia tetap dapat menikmati objek fidusia meskipun statusnya tidak lagi sebagai eigenaar melainkan sebagai detentor (houder).
Pada Pasal 5 ayat (1) UndangUndang Nomor 42 Tahun 1999 tentang Jaminan Fidusia (selanjutnya disebut UU Jaminan Fidusia) mengatur bahwa "untuk menjamin kepastian dan perlindungan hukum bagi kreditur maupun debitur, pengikatan jaminan fidusia harus dituangkan dalam akta otentik." Selanjutnya, Pasal 11 UU Jaminan Fidusia mengatur bahwa benda yang dibebani jaminan fidusia wajib didaftarkan pada kantor pendaftaran fidusia. Pendaftaran jaminan fidusia bertujuan untuk menjamin kepastian hukum, salah satunya kepastian eksekusi objek fidusia apabila debitur wanprestasi. Titel eksekutorial "Demi Keadilan Berdasarkan Ketuhanan Yang Maha Esa" termaktub pada kepala sertifikat jaminan fidusia. Dengan title tersebut, kreditur dapat melakukan eksekusi langsung tanpa proses pengadilan.

Kegiatan pembiayaan konsumen ${ }^{3}$ sebenarnya telah memiliki landasan hukum dalam peraturan perundangundangan yang diharapkan mampu mendukung industri pembiayaan sehingga dapat mencegah dan mengatasi permasalahan yang terjadi. Permasalahan antara konsumen dan lembaga pembiayaan ${ }^{4}$ seringkali terjadi karena adanya perbedaan pandangan hukum terhadap Pasal 11

Willy Putra and Haryati Widjaja, 'Penerapan Prinsip Kehati-Hatian Dalam Penyaluran Kredit (Studi Kasus Di Bank BRI Cabang Semarang)' (2019) 3 (1) Refleksi Hukum: Jurnal Ilmu Hukum 81, 84.

2 Ridwan Fathoni, Siti Malikhatun Badriyah dan $\mathrm{R}$ Suharto, 'Efektivitas Pemberlakuan Pendaftaran Jaminan Fidusia Secara Elektronik Terhadap Pembiayaan Bank Syariah (Studi Pada Bank Pembiayaan Rakyat Syariah Artha Amanah Ummat Kabupaten Semarang)' (2016) 5 (3) Diponegoro Law Journal 1, 2.

Vide Pasal 1 angka 7 Perpres Lembaga Pembiayaan.

Vide Pasal 1 angka 1 Perpres Lembaga Pembiayaan. 
UU Jaminan Fidusia. ${ }^{5}$ Pasal ini dikaitkan dengan penarikan unit kendaraan oleh lembaga pembiayaan yang terkadang melibatkan penegak hukum sehingga berdampak pada opini publik yang kurang tepat.

Berdasarkan Pasal 11 tersebut jaminan fidusia dianggap baru lahir setelah didaftarkan pada kantor pendaftaran fidusia. Namun, dewasa ini muncul persoalan yang berkaitan dengan pendaftaran jaminan fidusia yang mana lembaga pembiayaan tidak melakukan pendaftaran sehingga tidak memiliki sertifikat jaminan fidusia. Muncullah opini publik yang bersifat tendensius mengenai keabsahan penarikan tersebut. Berdasarkan uraian di atas, penulis tertarik untuk meneliti bagaimana pelaksanaan eksekusi objek jaminan fidusia tanpa titel eksekutorial yang sah?

Metode yang digunakan dalam penelitian ini adalah metode penelitian hukum normatif yaitu mengkaji dan menganalisa bahan-bahan hukum dan isu-isu hukum yang berkaitan dengan permasalahan yang diteliti. Penelitian ini dilakukan untuk memecahkan permasalahan yang timbul, sedangkan hasil penelitiannya berupa preskripsi tentang apa yang seharusnya dilakukan untuk mengatasi permasalahan yang timbul tersebut. Preskripsi diberikan dalam bentuk saran atau rekomendasi.

\section{PEMBAHASAN}

\section{Pendaftaran Jaminan Fidusia dan Pengaturannya di Indonesia}

Istilah fidusia berasal dari bahasa Belanda, yaitu fiducie, yang dalam Bahasa Inggris disebut fiduciary transfer of ownership, artinya kepercayaan. Fidusia juga diambil dari kata bahasa Latin yaitu fides yang berarti kepercayaan. Menurut Pasal 1 angka 1 UU Jaminan Fidusia, pengertian fidusia adalah pengalihan hak kepemilikan suatu benda atas dasar kepercayaan dengan ketentuan bahwa benda yang hak kepemilikannya dialihkan tersebut tetap dalam penguasaan pemilik benda.

Pada prinsipnya apabila suatu benda dijaminkan debitur kepada kreditur, maka benda tersebut akan diberikan kepada kreditur dengan penyerahan secara nyata. Namun pada fidusia tidak demikian, penyerahan jaminan fidusia dilakukan secara yuridise levering sehingga benda yang dijadikan objek fidusia tetap dalam penguasaan si debitur. Prinsip inilah yang dinamakan dengan constitutum possessorium. Pengaturan lembaga jaminan fidusia ini tidak ditemukan dalam Kitab UndangUndang Hukum Perdata (selanjutnya disebut KUHPerdata). Namun sejak diundangkannya UU Jaminan Fidusia, lembaga ini mulai memiliki dasar hukum yang kuat.

Pelaksanaan jaminan fidusia ini melalui 2 (dua) tahapan:6 1) tahapan pembebanan jaminan dan; 2) tahapan pendaftaran jaminan fidusia. Pembe-

\footnotetext{
$5 \quad$ Abednego Isa Latuihamallo, Dilema Dunia Multifinance, Sebuah Analisis Ilmiah Terhadap Fidusia dan Permasalahannya Dalam Dunia Multifinance (Cet. pertama, Grasindo 2014) 2.

$6 \quad$ Pasal 5 ayat (1) UU Jaminan Fidusia.
} 
banan jaminan fidusia dibuat dengan syarat-syarat sebagai berikut: ${ }^{7}$

1. Akta notaris;

2. dalam bahasa Indonesia;

3. merupakan akta jaminan fidusia yang sekurang-kurangnya memuat:

a. Identitas pihak pemberi dan penerima fidusia;

b. data perjanjian pokok yang dijaminkan fidusia;

c. uraian mengenai benda yang menjadi objek jaminan fidusia;

d. nilai penjaminan; dan,

e. nilai benda yang menjadi objek jaminan fidusia.

Pendaftaran fidusia merupakan syarat mutlak lahirnya jaminan fidusia. Pendaftaran dilakukan di Kantor Pendaftaran Fidusia pada Kementerian Hukum dan Hak Asasi Manusia. Permohonan pendaftaran jaminan fidusia dilakukan secara tertulis dengan melampirkan pernyataan pendaftaran jaminan fidusia yang memuat:8

1. Identitas pihak pemberi dan penerima fidusia;

2. tanggal, nomor akta jaminan fidusia, nama dan tempat kedudukan notaris yang membuat akta;

3. data perjanjian pokok yang dijamin fidusia;

4. uraian mengenai benda yang menjadi objek jaminan fidusia;

5. nilai penjaminan;

6. nilai benda yang menjadi objek jaminan fidusia.

Tata caranya diatur secara rinci dalam Peraturan Pemerintah No. 86 Tahun 2000. Sejak tahun 2013 pendaftaran jaminan fidusia dilaku- kan secara online yang pengaturannya diatur dalam bentuk Peraturan Menteri Hukum dan HAM No. 10 Tahun 2013 sebagai berikut: ${ }^{9}$

1. Permohonan pendaftaran jaminan fidusia diajukan kepada menteri;

2. pendaftaran diajukan secara tertulis dalam Bahasa Indonesia oleh penerima fidusia, kuasa atau wakilnya dengan melampirkan pernyataan pendaftaran jaminan fidusia;

3. Permohonan pendaftaran jaminan fidusia dilengkapi dengan:

a. Salinan akta notaris tentang pembebanan jaminan fidusia;

b. surat kuasa atau surat pendelegasian wewenang untuk melakukan pendaftaran jaminan fidusia;

c. bukti pembayaran biaya pendaftaran jaminan fidusia.

4. pernyataan pendaftaran jaminan fidusia dilakukan dengan mengisi formulir yang bentuk dan isinya ditetapkan dengan Keputusan Menteri;

5. pejabat yang menerima permohonan pendaftaran jaminan fidusia memeriksa kelengkapan persyaratan permohonan pendaftaran jaminan fidusia;

6. dalam hal persyaratan tidak lengkap, pejabat harus langsung mengembalikan berkas permohonan tersebut kepada pemohon untuk dilengkapi;

7. dalam hal kelengkapan persyaratan permohonan pendaftaran jaminan fidusia telah dipenuhi sesuai dengan ketentuan, pejabat mencatat jaminan fidusia dalam buku daftar fidusia pada tanggal 
yang sama dengan tanggal penerimaan permohonan pendaftaran;

8. penerbitan sertifikat jaminan fidusia dan penyerahannya kepada pemohon dilakukan pada tanggal yang sama dengan tanggal permohonan pendaftaran jaminan fidusia;

9. dalam hal terjadi kekeliruan penulisan dalam sertifikat jaminan fidusia yang telah diterima oleh pemohon dalam jangka waktu paling lambat 60 (enam puluh) hari setelah menerima sertifikat tersebut pemohon memberitahukan kepada Kantor Pendaftaran Fidusia untuk diterbitkan sertifikat perbaikan;

10. sertifikat perbaikan memuat tanggal yang sama dengan tanggal sertifikat semula dan penerbitan sertifikat perbaikan tidak dikenai biaya.

Pendaftaran sendiri memiliki arti yuridis sebagai suatu rangkaian yang tidak terpisah dari proses terjadinya perjanjian jaminan fidusia. Pendaftaran jaminan fidusia merupakan perwujudan dari asas publisitas dan kepastian hukum. Jaminan fidusia yang telah terdaftar dalam buku daftar fidusia dibuktikan dengan sertifikat jaminan fidusia yang dapat diunduh secara online. Pada sertifikat tersebut terdapat irah-irah "Demi Keadilan Berdasarkan Ketuhanan Yang Maha Esa" yang bermakna bahwa sertifikat fidusia mempunyai kekuatan eksekutorial yang sama dengan putusan pengadilan yang telah memperoleh kekuatan hukum tetap. Artinya apabila debitor wanprestasi, maka kreditur berhak untuk mengeksekusi atau menjual objek jaminan fidusia atas kekuasaan kreditur sendiri.

Lembaga jaminan fidusia mengalami perubahan yang mendasar khususnya setelah UU Jaminan Fidusia diundangkan. Perubahan pokoknya perihal kewajiban pendaftaran jaminan fidusia. Meskipun pendaftaran ini sangat penting, namun masih menimbulkan berbagai pertanyaan dan keraguan akan kewajiban pendaftaran tersebut. Perbedaan pendapat di kalangan ahli hukum ini masih menjadi persoalan. Sebagian mengatakan bahwa yang didaftarkan ialah akta jaminan fidusianya, sebagian yang lain mengatakan bukan hanya akta yang didaftarkan melainkan bendanya pun harus turut didaftar. Fakta yuridisnya, apabila dianalisa dari klausul akta jaminan fidusia yang dibuat notaris, ditemukan bahwa yang didaftarkan adalah akta jaminan fidusia dan benda jaminan fidusia. ${ }^{10}$

Pendaftaran jaminan fidusia mempunyai konsekuensi yuridis sebagaimana termaktub dalam Pasal 2 UU Jaminan Fidusia bahwa yang menjadi pemilik benda agunan ialah kreditur penerima fidusia, meskipun secara fisik debitur pemberi fidusia menguasai benda tersebut. Kedudukan pemberi fidusia yang sebelumnya menjadi pemilik berubah menjadi beziter. Pendapat ini memberikan arti bahwa adanya pemisahan hak milik jaminan secara yuridis dan hak milik jaminan secara rill. ${ }^{11}$

Pendaftaran jaminan fidusia melahirkan hak kebendaan dalam

10 Tan Kamelo, Hukum Jaminan Fidusia Suatu Kebutuhan yang Didambakan (Cet. pertama, Alumni 2014) 213.

$11 \quad$ Ibid., 216. 
jaminan fidusia yang ditandai dengan terbitnya sertifikat jaminan fidusia. Perjanjian jaminan fidusia sebagaimana termaktub dalam akta jaminan fidusia baru menimbulkan hak dan kewajiban saja bagi para pihak yang membuatnya sebagaimana perjanjian obligatoir pada umumnya. Dalam setiap perjanjian perdata pada umumnya mengandung dua segi antara lain: segi obligatoir dan segi penyerahan kebendaan.

Segi obligatoir sebagai sebab yang menimbulkan hak dan kewajiban bagi para pihak, sedangkan segi penyerahan kebendaan yang menimbulkan hak kebendaan. Perjanjian yang disepakati dan ditutup dengan penandatanganan akta perjanjian baru memenuhi segi obligatoir saja dan untuk menimbulkan hak kebendaan perlu adanya tindakan levering (penyerahan) yang akan menjadi sebab peralihan hak kebendaan dari debitur ke kreditur. Dalam perjanjian jaminan fidusia penyerahan hak milik tersebut tidak diikuti dengan penyerahan barangnya secara nyata karena adanya prinsip constitutum possessorium, sehingga segi kebendaan dalam perjanjian fidusia ditentukan oleh pendaftaran jaminan fidusia pada Kantor Pendaftaran Jaminan Fidusia.

\section{Eksekusi Berdasarkan Sertifikat Jaminan Fidusia}

Pada umumnya eksekusi bidang hukum perdata dilakukan melalui lembaga pengadilan baik karena suatu putusan hakim yang berkekuatan hukum tetap ataupun dokumen lain yang memiliki kekuatan eksekutorial yang dapat dilakukan eksekusi melalui fiat ketua pengadilan negeri seperti pada sertifikat jaminan fidusia. Menurut Harahap, eksekusi merupakan tindakan hukum yang dilakukan oleh pengadilan kepada pihak yang kalah dalam suatu perkara. ${ }^{12}$

Apabila piutang kreditur dijamin dengan jaminan yang mengandung titel eksekutorial seperti pada jaminan kebendaan fidusia maka kreditur dapat langsung meminta pelaksanaan penjualan lelang melalui fiat ketua pengadilan negeri tanpa harus melalui proses gugatan. ${ }^{13}$ UU Jaminan Fidusia juga telah memberikan wewenang kepada para pihak untuk memperjanjikan adanya kewenangan dalam melakukan penjualan objek jaminan atas kekuasaannya sendiri terhadap jaminan-jaminan kebendaan. ${ }^{14}$

Titel eksekutorial yang terdapat dalam sertifikat jaminan fidusia yang berbunyi "Demi Keadilan Berdasarkan Ketuhanan Yang Maha Esa" merupakan pernyataan yang mengandung suatu kewenangan bahwa dokumen (naskah) telah memiliki kekuatan eksekusi (pelaksanaan secara paksa) dengan bantuan alat negara. Atas adanya titel eksekutorial tersebut pemegang jaminan fidusia dapat mengajukan permohonan eksekusi kepada pengadilan dan pengadilan akan memenuhinya dengan prosedur eksekusi. ${ }^{15}$

Sesuai dengan ketentuan Pasal 196 ayat (3) HIR, kreditur harus mengajukan permohonan kepada ketua pengadilan, agar dilaksanakan

12 M. Yahya Harahap, Ruang Lingkup Permasalahan Eksekusi Bidang Perdata (Cet. ke-3, Gramedia 1988) 1.

13 DY Witanto, Hukum Jaminan Fidusia Dalam Perjanjian Pembiayaan Konsumen (Aspek Perikatan, Pendaftaran, Dan Eksekusi) (Cet. pertama, Mandar Maju 2015) 229.

14 Vide Pasal 29 ayat (1) huruf a UU Jaminan Fidusia.

15 Tan Kamelo, Op.Cit., 103. 
eksekusi atas benda jaminan berdasarkan titel eksekutorial sertifikat jaminan fidusia. Ketua pengadilan akan memanggil dan memerintahkan debitur untuk melaksanakan kewajibannya. Setelah waktu tersebut lampau dan debitur tetap tidak dapat melunasi hutangnya, maka ketua pengadilan akan memerintahkan juru sita untuk menyita benda jaminan. ${ }^{16}$ Pelaksanaan eksekusi tersebut dilakukan dengan cara menjual objek jaminan fidusia di muka umum (pelelangan) atau dengan cara yang dianggap patut oleh ketua pengadilan. ${ }^{17}$

Lalu, kapan sebenarnya hak eksekusi itu muncul, apakah pada saat perjanjian mengenai penjaminan atas pembiayaan yang diberikan itu disepakati ataukah pada saat debitur dinyatakan wanprestasi? Hak parate eksekusi memang lahir pada saat perjanjian jaminan disepakati oleh para pihak, namun hak tersebut dapat digunakan jika debitur wanprestasi. ${ }^{18}$ Apabila dalam pelaksanaan pembiayaan konsumen debitur tidak wanprestasi, maka hak tersebut dinyatakan gugur dengan sendirinya sejak utang yang dijaminkan dibayar lunas. Hal ini merupakan konsekuensi dari sifat accessoir yang melekat pada perjanjian jaminan yang selalu akan mengikuti perjanjian pokoknya.
Sifat dari perjanjian jaminan fidusia ialah perjanjian ikutan (tambahan) yang keabsahannya tergantung pada perjanjian pokoknya. Suatu perjanjian yang bersifat ikutan (accessoir) memiliki ciri-ciri sebagai berikut: 19

1. Tidak dapat berdiri sendiri;

2. adanya/ timbulnya maupun hapusnya bergantung pada perikatan pokoknya;

3. apabila perikatan pokoknya dialihkan, maka perjanjian ikutan ini juga turut beralih.

Perjanjian pembiayaan yang diikuti dengan perjanjian fidusia sesungguhnya sebagai penambah keyakinan atas kesediaan, kesanggupan dan kemampuan debitur untuk melunasi kewajiban hutangnya. ${ }^{20} \mathrm{Hak}$ jaminan yang terkandung dalam fidusia adalah hak untuk pelunasan utang (vehaalsrecht) bukan mengandung hak untuk memiliki kebendaan (verval beding). ${ }^{21}$ Kreditur pemegang jaminan fidusia diberikan hak oleh UU maupun hak untuk memperjanjikan kuasa untuk menjual sendiri objek jaminan apabila debitur cidera janji (wanprestasi). Sehingga jika nilai penjualan melebihi jumlah hutang debitur, sisa penjualan wajib dikembalikan kepada debitur. ${ }^{22}$ Hak kebendaan semacam ini, tentunya memberikan fungsi yang besar terhadap

\footnotetext{
16 Vide Pasal 197 dan Pasal 200 HIR.

17 Khifni Kafa Rufaida, 'Keotentikan Akta Jaminan Fidusia yang Tidak Ditandatangani di Hadapan Notaris Setelah Berlakunya Sistim Pendaftaran Fidusia Secara Online' (Tesis, Universitas Diponegoro 2014) 64.

18 Vide Pasal 1243 KUH Perdata.

19 J. Satrio, Hukum Jaminan, Hak Jaminan Kebendaan, Hak Tanggungan (Cet. pertama, Citra Aditya Bakti 1997) 110.

20 Martha Eri Safira, 'Analisis Perjanjian Jaminan Fidusia Terhadap Parate Eksekusi dan Perlindungan Hukumnya Bagi Kreditur (Studi Kasus Pada BMT dan BPR Syariah di Ponorogo)' (2014) 11 (1) Justicia Islamica 119, 124.

21 Tan Henny Tanuwidjaya, 'Parate Eksekusi Hak Tanggungan Kontra Fiat Pengadilan' (2016) 10 (1) Refleksi Hukum: Jurnal Ilmu Hukum 99, 104.

22 Vide Pasal 34 UU Jaminan Fidusia.
} 
kreditur penerima fidusia, khususnya apabila debitur cidera janji.

Pada tanggal 7 Oktober 2012 Pemerintah mengeluarkan Peraturan Menteri Keuangan No. 130/PMK.010/ 2012, ada beberapa hal yang perlu diperhatikan dalam peraturan ini:

1. Pasal 1 ayat (1) mengatur bahwa "Perusahaan Pembiayaan yang melakukan pembiayaan konsumen untuk kendaraan bermotor dengan pembebanan jaminan fidusia wajib mendaftarkan jaminan fidusia dimaksud pada Kantor Pendaftaran Fidusia “. Ketentuan Pasal ini secara tegas dapat digaris bawahi bahwa pendaftaran yang memiliki manfaat penting ini seharusnya dilaksanakan oleh lembaga pembiayaan. Namun kembali lagi, bahwa pendaftaran jaminan fidusia ditujukan oleh lembaga pembiayaan yang ingin mendapatkan manfaat atas kelebihan-kelebihan UU Jaminan Fidusia;

2. Pasal 2 mengatur bahwa "perusahaan pembiayaan wajib mendaftarkan jaminan fidusia pada Kantor Pendaftaran Fidusia paling lama 30 (tiga puluh) hari kalender terhitung sejak tanggal perjanjian pembiyaan konsumen." Ketentuan ini bersifat ambigu, sebab seolaholah menjadi syarat keabsahan perjanjian pembiayaan. Padahal perlu dicermati, bahwa suatu pendaftaran jaminan fidusia bisa dilaksanakan dengan suatu pembebanan jaminan fidusia. Tanpa adanya pembebanan jaminan fidusia, pendaftaran tidak dapat dilakukan. Sebaliknya, tanpa dilakukan pendaftaran, pembebanan atas unit kendaraan dapat saja dilakukan berdasarkan pada perjanjian pokok (perjanjian pembiayaan) yang telah disepakati. Mengingat syarat sahnya perjanjian tercantum pada Pasal 1320 jo Pasal 1338 KUH Perdata, yang memberikan kebebasan absolut bagi para pihak yang membuat perjanjian. Keduanya berhak menentukan formalitas dan konsep perjanjian yang dibuat sepanjang perjanjian tersebut tidak melanggar ketertiban umum, kesusilaan dan keadilan.

\section{Pelaksanaan Eksekusi Objek Jaminan Fidusia tanpa Titel Eksekutorial yang Sah}

Beberapa perbedaan pendapat hukum dipicu karena adanya pro dan kontra atas kewajiban pendaftaran jaminan fidusia oleh perusahaan pembiayaan. Dari ketentuan Pasal 11 dapat dipastikan bahwa pendaftaran jaminan fidusia menjadi tolak ukur keabsahan hukum dari suatu perjanjian pembiayaan. Padahal perjanjian pembiayaan berlaku sebagai UU bagi mereka yang membuat dan tunduk pada hukum perjanjian. ${ }^{23}$ Asas pacta sunt servanda yang termuat dalam KUH Perdata merupakan dasar kebebasan membuat perjanjian dan pelaksanaan perjanjian dengan itikad baik juga berlaku dalam perjanjian kredit perbankan. Sehingga dengan adanya perjanjian pembiayaan sebetulnya perjanjian tersebut sudah mengikat kedua belah pihak.

Prinsip perjanjian kredit pada dasarnya pemberian kredit oleh bank kepada nasabah peminjam selaku debitur selalu didasarkan kepada 2 (dua) prinsip dasar yaitu prinsip 
kepercayaan dan prinsip kehati-hatian (prudential principle).

Salah satu pelaksanaan dari kedua prinsip di atas dengan menerapkan prinsip know your customer. ${ }^{24}$ Prinsip mengenal nasabah ini digunakan untuk mengetahui identitas nasabah, memantau kegiatan transaksi nasabah termasuk pelaporan transaksi yang mencurigakan.

Beberapa permasalahan yang berkaitan dengan pendaftaran jaminan fidusia antara lain mengenai cara debt collector menarik unit kendaraan bermotor terhadap nasabah yang lalai tanpa sertifikat merupakan suatu perbuatan yang melawan hukum? Sebelum membahas mengenai salah tidaknya perbuatan debt collector tersebut, secara komprehensif yang bersifat objektif dengan mendasarkan pada norma atau teori hukum yang tepat bahwa dalam kegiatan pembiayaan akan diawali dengan suatu perjanjian yang disebut perjanjian pembiayaan. Perjanjian pembiayaan tersebut merupakan perjanjian hutang piutang/perjanjian pokok yang mana jaminan utamanya adalah pembayaran hutang debitur secara penuh kepada kreditur. Berdasarkan KUH Perdata perjanjian tersebut telah berlaku mengikat. 25

Kaidah hukum perjanjian yang termaktub dalam Pasal 1320 KUH Perdata jo Pasal 1338 KUH Perdata, perjanjian pembiayaan yang telah disepakati para pihak mempunyai konsekuensi hukum. Perjanjian itu tidak dapat ditarik kembali selain dengan kesepakatan kedua belah pihak atau karena adanya alasanalasan yang ditentukan oleh UU. Perjanjian harus dilaksanakan dengan itikad baik. Hukum jaminan terdiri atas beberapa asas. Badrulzaman mengatakan bahwa asas-asas hukum jaminan antara lain: 26 1. Pancasila sebagai asas filosofi/idealis, 2. Undang-Undang Dasar Negara Republik Indonesia Tahun 1945 sebagai asas konstitusional, 3. Ketetapan Majelis Permusyawaratan Rakyat sebagai asas politik, dan 4. UU sebagai asas operasional. Namun demikian, jaminan umum ini belum sepenuhnya memberikan kepuasan kepada kreditur karena dimungkinkan konsumen pembiayaan memiliki kreditur-kreditur yang lain. Dengan demikian, ada kemungkinan debitur tersebut tidak akan dapat memenuhi piutangnya secara penuh.

Dalam praktek masyarakat, lembaga pembiayaan menetapkan suatu transaksi pembiayaan konsumen dengan konsep kontrak yang tidak hanya mengatur kewajiban debitur dalam membayar hutangnya secara penuh. Namun juga, turut membebankan benda/ kendaraan tertentu yang dibiayai oleh lembaga pembiayaan, yang mana benda tersebut atas dasar kesepakatan bersama digunakan sebagai jaminan yang mempunyai konsekuensi hukum. Apabila debitur lalai, maka debitur secara sukarela harus menyerahkan kendaraan tersebut kepada kreditur untuk dijual dan digunakan untuk pelunasan piutang. Oleh karena itu, dapat dikatakan bahwa perjanjian pembiayaan ini melahirkan jaminan umum

Willy Putra and Haryati Widjaja, Op.Cit., 86.

Vide Pasal 1131 KUH Perdata.

Fatma Pararang, 'Implementasi Jaminan Fidusia Dalam Pemberian Kredit di Indonesia' (2014) 1

(2) Jurnal LPPM Bidang Ekososbudkum 56, 66. 
saja. Dengan kata lain, debt collector yang melakukan penarikan kendaraan pada dasarnya mengacu pada keinginan atau perintah debitur atau konsumen sendiri yang telah disepakati bersama dalam perjanjian pembiayaan. Pada perjanjian tersebut, debitur memberikan kuasa kepada kreditur untuk mengambil unit jaminan dan menjualnya dalam rangka memenuhi seluruh utang debitur. Kuasa tersebut merupakan salah satu instrumen yang diperjanjikan dan menjadi bagian yang tidak dapat dipisahkan dalam perjanjian pokok.

Tanpa dilakukannya pendaftaran, bukan berarti hakikat dari pembebanan benda jaminan menjadi hilang. Sebab, penarikan benda jaminan dapat disepakati dan didasarkan pada perjanjian pembiayaan sebagai perjanjian pokok. Hal ini berarti, penarikan juga telah didasarkan pada perintah debitur sendiri atau setidaknya debitur memang mengetahui dan memahami bahwa kendaraan bermotor yang dikuasainya telah dibebankan sebagai jaminan untuk melunasi hutangnya terhadap lembaga pembiayaan. ${ }^{27}$

Istilah "penarikan benda jaminan fidusia" ditemukan juga dalam Pasal 30 UU Jaminan Fidusia bahwa "debitur wajib menyerahkan objek jaminan fidusia dalam rangka pelaksanaan eksekusi". Dalam konteks penarikan kendaraan bermotor berdasarkan sertifikat fidusia, lembaga pembiayaan dianggap telah tunduk dan memenuhi syarat serta ketentuan yang berlaku di dalam UU Jaminan Fidusia tersebut.
Peristiwa penarikan oleh debt collector ini, lahir dari asumsi publik yang bersifat subjektif dan tendensius, yang memojokkan posisi lembaga pembiayaan selaku kreditur yang memberikan fasilitas pembiayaan. Opini publik ini sering menyalahkan lembaga pembiayaan sebagai pihak yang arogan dan melakukan tindakan sewenang-wenang yang melanggar hukum. Padahal kenyataannya, jika kronologisnya diuraikan dapat dikatakan bahwa lembaga pembiayaan telah memberikan toleransi waktu yang cukup bagi nasabah atau konsumen yang lalai untuk melakukan kewajiban pembayaran hutang kepada lembaga pembiayaan. Ini membuktikan bahwa penarikan unit kendaraan tidak dilakukan dengan semena-mena.

Penarikan yang dilakukan lembaga pembiayaan Bank Perkreditan Rakyat Pratama Dana Abadi selama ini selalu diawali dengan pendekatan personal $^{28}$ melalui kunjungan ke tempat tinggal debitur, melakukan penagihan kepada debitur atau dengan memberikan surat peringatan sampai 3 (tiga) kali berturut-turut (somasi) agar debitur segera melunasi hutang/cicilannya. Ketika pendekatan ini telah dilakukan oleh kreditur dan debitur belum memenuhi kewajibannya, maka sudah sepantasnya pihak lembaga pembiayaan (kreditur) melakukan penarikan sesuai dengan perjanjian pembiayaan yang telah dibuat sebelumnya. Penarikan pun dilakukan oleh marketing yang bertindak juga sebagai remedial dan tanpa melalui oknum hukum

\footnotetext{
27 Abednego Isa Latuihamallo, Op.Cit., 149.

28 Wawancara dengan Ragil Yulianto, Staff Legal, BPR Pratama Dana Abadi (Ungaran, 22 Juli 2019).
} 
lainnya.29 Apakah penarikan semacam ini dapat dibenarkan? Penarikan kendaraan semacam ini dapat dibenarkan, meskipun hanya dengan dasar perjanjian pembiayaan maupun dengan dasar adanya sertifikat jaminan fidusia. Perbedaan yang mendasarkan hanyalah terletak pada sifat preferensi kreditur.

Konstruksi pembiayaan konsumen memiliki dua macam jaminan. Pertama, jaminan utama/pokok yang merupakan pernyataan kesanggupan debitur untuk memenuhi segala kewajibannya sesuai dengan yang ia sepakati dengan kreditur dalam perjanjian pembiayaan. Kedua, jaminan tambahan yaitu pembebanan terhadap benda tertentu yang dapat diidentifikasikan secara spesifik yang diperuntukkan sebagai jaminan kebendaan untuk memenuhi pelunasan seluruh hutang debitur kepada kreditur. Apabila debitur lalai di kemudian hari maka pembebanan jaminan tambahan tersebut dapat dipergunakan untuk melunasi pembayaran hutang kepada kreditur.

Ciri utama dari jaminan fidusia adalah benda jaminan harus tetap berada dalam penguasaan debitur. Prinsip ini harus dipenuhi dalam jaminan fidusia, sebab jika benda jaminan dikuasai oleh kreditur maka perjanjian jaminan fidusia menjadi tidak sah. Namun, berbeda halnya jika debitur wanprestasi, kreditur penerima jaminan fidusia berwenang menarik benda jaminan tersebut untuk dijual guna pelunasan hutang debitur. Tindakan tersebut bukan merupakan perbuatan hukum yang bertentangan dengan UU. Bahkan, sebagaimana yang termaktub dalam Pasal 30 tersebut di atas, debitur pemberi fidusia wajib menyerahkan benda jaminan fidusia untuk dijual. Beberapa kasus yang masuk ranah pengadilan pun membenarkan tindakan penarikan tersebut. Sebagai contoh pada Putusan Pengadilan Negeri Siantar dalam perkara Sejahtera Bank Umum v Lo Tjin Kuang dan Lo Ah Lian, No. 80/Pdt.G/1992/PN-PMs tertanggal 2 Februari 1993,30 begitu pula dengan Putusan Pengadilan Negeri Medan dalam perkara Sejahtera Bank Umum v Chairul Azhari Siregar No. 105/Pdt.G/1994/PN-Mdn tertanggal 30 Agustus 1994. ${ }^{31}$

Pasal 3 Peraturan Menteri Keuangan No. 130/PMK.010/2012 mengatur bahwa perusahaan pembiayaan dilarang melakukan penarikan benda jaminan fidusia berupa kendaraan bermotor apabila Kantor Pendaftaran Fidusia belum menerbitkan sertifikat jaminan fidusia dan menyerahkannya kepada lembaga pembiayaan. Pasal ini seolah-olah tidak mengesahkan perjanjian pokok yang dibuat antara lembaga pembiayaan dan konsumen (debitur), karena menilai keabsahan perjanjian pembiayaan ditentukan oleh perjanjian tambahannya yakni pendaftaran jaminan fidusia. Padahal kesepakatan yang ada dalam perjanjian pembiayaan antara para pihak sah jika dijadikan dasar penarikan.

Pemberian jaminan atas suatu kredit dapat beragam bentuknya, baik yang disepakati dalam perjanjian pokok ataupun dalam akta jaminan fidusia yang dibuat secara tersendiri.

\footnotetext{
29 Wawancara dengan Ifa Fitri Aryani, Staff Admin Kredit, BPR Pratama Dana Abadi (Ungaran, 22 Juli 2019).

30 Tan Kamelo, Op.Cit., 278.

31 Ibid., 317.
} 
Hal ini bergantung dari kesepakatan antara kedua belah pihak. Hukum perdata pun mengenal berbagai macam bentuk jaminan, termasuk di dalamnya jaminan umum yang termaktub dalam Pasal $1131 \mathrm{KUH}$ Perdata: "Segala kebendaan si berhutang yang bergerak maupun yang tidak bergerak, baik yang sudah ada maupun yang baru akan ada di kemudian hari, menjadi tanggungan untuk segala perikatan perseorangan." Lalu seberapa besar tingkat pentingnya sertifikat jaminan fidusia jika dengan perjanjian pembiayaan saja debitur sudah terikat?

Seiring dengan perkembangan ekonomi, jaminan umum yang dimaksud dalam Pasal 1131 KUH Perdata tersebut tidak sepenuhnya dapat memberikan perlindungan dan kepastian hukum bagi kedua belah pihak terlebih pada kreditur. Untuk itulah hukum perdata mengatur adanya jaminan khusus contohnya jaminan fidusia. Jaminan fidusia dilakukan dengan cara constitutum possesorium yaitu benda yang diserahkan hak kepemilikannya tersebut kepada kreditur tetapi fisiknya masih dikuasai oleh debitur/ pemberi fidusia.

Untuk menyikapi perkembangan ekonomi saat ini, UU Jaminan Fidusia tidak hanya memberikan perlindungan hukum kepada kreditur/penerima fidusia, melainkan juga diharapkan memberikan kepastian hukum yang kuat bagi pengguna lembaga jaminan. Menurut Gustav Radbruch, hukum mempunyai tiga aspek penting yakni, keadilan, finalitas dan kepastian. UU Jaminan Fidusia dibuat agar pelaksanaannya dapat menimbulkan kepastian hukum. Inti dari kepastian hukum juga bukan hanya terletak pada batas-batas daya berlakunya menurut wilayah atau kelompok tertentu melainkan terletak pada: ${ }^{32}$

1. Kepastian tentang bagaimana subjek hukum harus berperilaku secara konsistensi dan berani menerima konsekuensi;

2. kepastian tentang bagaimana para sruktural hukum harus menetapkan hukum atau berperilaku sesuai hukum atau kepastian prosedural;

3. kepastian adanya keterbukaan terhadap kritik dan berani menerima kritik;

4. kepastian adanya orientasi yang jelas yaitu pada hukum yang adil dan kesejahteraan masyarakat yaitu people centre oriented.

Tahapan penting proses jaminan fidusia ialah pembebanan dan pendaftaran jaminan fidusia yang melahirkan hak kebendaan. Salah satu prinsip dalam hukum jaminan kebendaan adalah prinsip publisitas atau asas keterbukaan. Prinsip ini dimaksudkan agar pihak-pihak lain yang berkepentingan terhadap benda yang dijaminkan mengetahui tentang adanya pembebanan jaminan benda tersebut. Pencatatan atau pendaftaran memungkinkan pihak yang berkepentingan terhadap objek jaminan fidusia tersebut mengetahui adanya pembebanan pada objek jaminan fidusia. Pendaftaran jaminan fidusia juga memberikan kepastian hukum kepada pihak-pihak yang berkepentingan dan memberikan kedudukan didahulukan dari kreditur-kreditur yang lain.

Prinsip publisitas pada jaminan fidusia dapat terpenuhi dengan

32 Peter Mahmud Marzuki, Pengantar Ilmu Hukum (Cet. pertama, Kencana Prenada Media Group 2009) 158. 
adanya kewajiban pendaftaran jaminan fidusia di kantor pendaftaran fidusia. Dengan pendaftaran ini, maka informasi mengenai benda yang menjadi objek jaminan fidusia terbuka dan dapat diketahui oleh umum. Sedangkan, perjanjian jaminan fidusia yang tidak didaftarkan akan berakibat pada:

1. Hilangnya hak preferen, dalam arti bahwa kedudukan kreditur hanya sebatas sebagai kreditur konkuren yang tidak memegang jaminan apapun;

2. tidak memiliki titel eksekutorial sehingga tidak adanya kepastian hukum pada jaminan fidusia.

Pendaftaran jaminan fidusia juga melahirkan sertifikat jaminan fidusia mempunyai kekuatan eksekutorial yang sama dengan putusan pengadilan yang telah memperoleh kekuatan hukum tetap. Hal ini perlu untuk dicermati, bahwa salah satu asas eksekusi menyatakan bahwa eksekusi hanya dilakukan terhadap putusan yang bersifat condemnatoir, yaitu putusan yang berisi penghukuman kepada pihak yang dikalahkan untuk memenuhi prestasi. ${ }^{33}$ Putusan yang amar atau dictum-nya tidak mengandung unsur penghukuman tidak dapat dieksekusi. Lalu bagaimana dengan sertifikat jaminan fidusia? Bisakah dilakukan eksekusi?

Sertifikat jaminan fidusia merupakan akta pejabat yang berisi pernyataan pejabat tentang adanya jaminan fidusia yang berisi pernyataan konstitutif dari pejabat yang menerbitkan akta. ${ }^{34}$ Pernyataan tersebut merupakan salinan dari buku daftar fidusia yang merupakan rangkaian dari proses pendaftaran jaminan fidusia guna memenuhi asas publisitas. Oleh karena itu, menurut hemat penulis, sertifikat jaminan fidusia tidak memuat kewajiban atau syarat-syarat yang bersifat condemnatoir. Dengan kata lain, maka sertifikat jaminan fidusia tidak serta merta dipersamakan dengan putusan pengadilan yang telah memperoleh kekuatan hukum tetap serta tidak dapat dilakukan tindakan eksekusi (non-eksekutabel).

Tata cara pelaksanaan eksekusi diatur dalam Pasal 29 ayat (1) UU Jaminan Fidusia: "apabila debitor atau pemberi fidusia cidera janji, eksekusi terhadap benda yang menjadi obyek jaminan fidusia dapat dilakukan dengan cara:

a. pelaksanaan titel eksekutorial sebagaimana dimaksud dalam pasal 15 ayat (2) oleh penerima fidusia;

b. penjualan benda yang menjadi obyek jaminan fidusia atas kekuasaan penerima fidusia sendiri melalui pelelangan umum serta mengambil pelunasan piutangnya dari hasil penjualan;

c. penjualan di bawah tangan yang dilakukan berdasarkan kesepakatan pemberi dan penerima fidusia jika dengan cara demikian dapat diperoleh harga tertinggi yang menguntungkan para pihak." Berdasarkan ketentuan di atas, kreditur/penerima fidusia mempunyai pilihan eksekusi terhadap benda jaminan yaitu: eksekusi berdasarkan titel eksekutorial, parate executie melalui pelelangan umum dan penjualan di bawah tangan. Pelaksa-

33 Sudikno Mertokusumo, Hukum Acara Perdata Indonesia (Cet. pertama, Liberty 1985) 189.

34 Supianto, Hukum Jaminan Fidusia, Prinsip Publisitas Pada Jaminan Fidusia (Cet. pertama, Garudhawaca 2015) 161. 
naan eksekusi berdasarkan titel eksekutorial sebagaimana dimaksud dalam Pasal 15 ayat (2) UU Jaminan Fidusia yakni: sertifikat jaminan fidusia mempunyai kekuatan eksekutorial yang sama dengan putusan pengadilan yang telah memperoleh kekuatan hukum tetap. Pemegang sertifikat jaminan fidusia berkedudukan seperti seseorang yang sudah memegang putusan pengadilan yang telah mempunyai kekuatan hukum tetap. Oleh karena itu, pelaksanaan sertifikat jaminan fidusia sama dengan pelaksanaan suatu keputusan pengadilan yaitu sesuai dengan ketentuan Pasal $200 \mathrm{HIR}$, berdasarkan pada fiat eksekusi dari ketua pengadilan. ${ }^{35}$

Meskipun pelaksanaan sertifikat jaminan fidusia tetap membutuhkan fiat eksekusi, namun pendaftaran fidusia tetap wajib dilakukan. Sebab, perjanjian jaminan fidusia yang tidak didaftarkan tidak akan menimbulkan hak kebendaan, akan tetapi hanya menimbulkan hak perorangan yang bersumber dari perjanjian obligatoir. Sehingga sifat-sifat yang melekat hanyalah yang terdapat dalam hak perorangan saja, yaitu bersifat relatif dalam arti hak tersebut hanya dapat dipertahankan terhadap orang-orang tertentu saja. Selanjutnya, perjanjian jaminan tersebut tidak melahirkan hak kebendaan, maka prinsip-prinsip hukum jaminan kebendaan pun tidak melekat pada perjanjian jaminan fidusia yang tidak didaftarkan, antara lain sifat mutlak, droit de suite, droit de preference, spesialitas dan publisitas: 36

a. Hak kebendaan memiliki sifat mutlak atau absolut dalam arti bahwa hak tersebut dapat ditegakkan terhadap siapapun, tidak hanya kepada pihak-pihak dalam perjanjian saja, tetapi juga kepada pihak lain yang terkait di kemudian hari; 37

b. ciri khas hak kebendaan adalah bersifat droit de suite (zaaksgevlog) yang artinya bahwa hak kebendaan akan tetap mengikuti bendanya kemanapun atau ke tangan siapapun benda itu berada, karena sifatnya yang selalu melekat pada bendanya. Apabila benda tersebut dipindahtangankan, maka yang bersangkutan wajib pula menghormatinya; 38

c. prinsip droit de preference mempunyai arti bahwa hak jaminan fidusia memberikan kedudukan didahulukan bagi kreditur pemegang sertifikat jaminan fidusia terhadap krediturkreditur lainnya. Dengan adanya preferensi ini akan menguntungkan pihak penerima fidusia karena kreditur-kreditur lain (konkuren) harus mengalah. Hak preference ini tidak akan hapus karena terjadinya kepailitan atau likuidasi; 39

d. asas spesialitas dimaksudkan bahwa jaminan fidusia dapat dibebankan terhadap benda yang menjadi objek jaminan fidusia yang ditentukan secara spesifik. Dianutnya asas ini dapat dipahami bahwa jaminan fidusia hanya dapat dibebankan atas benda-benda yang ditentukan di dalam akta pembebanan jaminan 
fidusia; 40

e. prinsip publisitas sebagai asas keterbukaan mengenai adanya hak-hak kebendaan kepada pihak ketiga yang berkepentingan terhadap objek jaminan fidusia. Cara yang paling mudah bagi pihak ketiga untuk mengetahui dengan cara pencatatan dan pendaftaran jaminan fidusia yang terbuka untuk umum. Pencatatan dan pendaftaran tersebut dimaksudkan agar hak-hak yang diperoleh seseorang yang didasarkan pada perjanjian tersebut melahirkan perikatan pada pihak debitur dapat diketahui oleh masyarakat luas. Dengan diketahuinya perbuatan hukum tersebut, maka pihak penerima fidusia dapat mempertahankan haknya atas pelaksanaan kewajiban debitur tidak hanya kepada debitur saja, melainkan kepada siapapun yang bermaksud melakukan suatu tindakan terhadap benda yang menjadi objek perikatan. ${ }^{41}$

Secara filosofis, perlunya prinsip publisitas dalam jaminan fidusia merupakan cerminan prinsip keadilan bagi pihak-pihak yang terkait dalam pelaksanaan jaminan fidusia. Pendaftaran merupakan suatu hal yang sangat penting dalam bidang hukum kebendaan. Meskipun pada prinsipnya pendaftaran tersebut diserahkan sepenuhnya kepada para pihak yang melangsungkan suatu perbuatan hukum. Pendaftaran tersebut sebetulnya ditujukan untuk melindungi kepentingan pihak ketiga yang ingin mengetahui adanya suatu perbuatan hukum tertentu atas suatu kebendaan tertentu, maka ia dapat memeriksa melalui publikasi yang terbuka untuk umum tersebut. Apabila pendaftaran tidak dilakukan, maka akan mengakibatkan perbuatan hukum tersebut tidak mengikat pihak ketiga.

Jaminan kebendaan dilakukan dengan cara membebani suatu benda tertentu dengan suatu lembaga jaminan kebendaan, seperti fidusia yang bertujuan untuk memberikan kepastian bagi pelunasan suatu piutang tertentu. Dengan adanya pemberian jaminan, maka kreditur memiliki kedudukan istimewa (privilege) untuk menagih pelunasan piutangnya lebih dahulu dari pada para kreditur lainnya. Tentunya kedudukan yang istimewa ini tidak akan didapatkan pada jaminan umum yang dimaksud dalam Pasal $1131 \mathrm{KUH}$ Perdata sebagaimana yang telah disebutkan di atas.

Pelaksanaan penarikan jaminan fidusia pada prakteknya dilakukan melalui 2 (dua) cara: Pertama, dapat didasarkan pada perjanjian pokok baik dibuat dibawah tangan maupun autentik. Kedua, didasarkan pada sertifikat jaminan fidusia sebagaimana ketentuan UU Jaminan Fidusia yang berlaku. Sehingga ketentuan wajib sebagaimana dimaksud dalam Pasal 11 selama ini diartikan sebagai sebuah 'pilihan', bahwa apabila lembaga pembiayaan tunduk dan patuh pada ketentuan pendaftaran jaminan fidusia tersebut, maka ia akan mendapatkan manfaat dari pendaftaran jaminan fidusia. Pada kasus ini, hukum diartikan secara fleksibel, tidak kaku dan dapat dipertimbangkan sesuai dengan situasi dan kondisi yang ada pada lapangan. Dalam suatu perjanjian hal yang terpenting adalah 
taat pada asas itikad baik dan tidak bertentangan dengan ketertiban umum. Sama halnya dengan pendaftaran jaminan fidusia, dapat dijadikan sebagai pilihan bagi mereka yang menginginkan manfaat dari pendaftarannya.

Namun demikian, pendapat tentang 'pendaftaran jaminan fidusia adalah pilihan' tidaklah dapat dibenarkan. Apabila dilihat berdasarkan daya kerjanya suatu aturan hukum. Menurut Van Apeldoorn hukum dapat dibedakan menjadi hukum yang bersifat memaksa (dwingend recht) dan hukum yang bersifat mengatur (aanvullend recht).

Kata "memaksa" bermakna bahwa pembuat UU tidak memberikan keleluasaan kepada para pihak untuk menerapkan atau tidak menerapkan aturan tersebut. Dengan demikian, aturan tersebut tidak boleh disampingi oleh mereka yang melakukan perbuatan hukum. Berbeda halnya dengan hukum yang bersifat mengatur yang memiliki makna bahwa hukum akan dijadikan acuan bagi para pihak manakala para pihak tidak membuat sendiri aturan yang berlaku bagi mereka. Hukum yang bersifat mengatur memberikan disposisi kepada para pihak dan mengisi kekosongan aturan untuk hal-hal yang belum diatur oleh para pihak yang melakukan perbuatan hukum, tetapi para pihak pun dapat melakukan penyimpangan aturan tersebut dan menetapkan sendiri aturan-aturan yang akan diberlakukan bagi mereka.

Pendaftaran sebagaimana dimaksud dalam Pasal 11 UU Jaminan Fidusia merupakan suatu norma yang bersifat memaksa, artinya ketentuan tersebut harus dipatuhi, tidak boleh disimpangi, termasuk membuat peraturan sendiri yang menyimpang dari yang telah ditentukan. Sifat memaksa ini dapat dilihat dari dua aspek yakni hukum benda pada asasnya menganut sistem tertutup dan adanya kata "wajib" dalam Pasal tersebut.

Salah satu hal yang harus menjadi perhatian terkait dengan pendaftaran jaminan fidusia ialah mengenai jangka waktu penjaminan fidusia. Ketentuan mengenai jangka waktu penjaminan fidusia ini belum diatur secara tegas. Sehingga berdampak pada keberlakuan dari jaminan fidusia itu sendiri. Dalam pendaftaran jaminan fidusia, notaris dan/atau lembaga pembiayaan diminta untuk menetapkan jangka waktu penjaminan atau jangka waktu pelunasan yang biasanya disebut dengan istilah tenor. Artinya ketika tenor telah terlampaui, maka jaminan harus dieksekusi/dijual. Pemberian jangka waktu penjaminan ini tidak akan menimbulkan masalah jika hutang debitur dapat dilunasi sesuai dengan tenor yang telah disepakati. Namun, akan menimbulkan masalah jika debitur meminta untuk dilakukan perpanjangan tenor untuk pelunasan hutang. Sebagaimana praktek yang ada selama ini, banyak lembaga pembiayaan yang bersedia bahkan menawarkan untuk dilakukan perpanjangan jangka waktu pelunasan pembiayaan.

Perpanjangan jangka waktu pelunasan (tenor) ini seharusnya disikapi dengan pembaharuan data pendaftaran jaminan fidusia secara online. Ketentuan ini belum diatur secara tegas dalam suatu peraturan, sehingga dapat menimbulkan permasalahan baru dan dapat merugikan pihak penerima fidusia. Sebab, apabila pembaharuan tidak dilakukan, maka dengan sendirinya jaminan fidusia menjadi hapus. Apabila di kemudian hari debitur wanprestasi maka 
penarikan kendaraan yang dilakukan oleh penerima fidusia (kreditur) dianggap tidak beralas hukum. Sehingga, posisi kreditur berubah menjadi kreditur konkuren. Untuk itu ketentuan mengenai pembaharuan data pendaftaran jaminan fidusia harus dipertegas dalam peraturan perundang-undangan.

Kewajiban pendaftaran jaminan fidusia pun sering menimbulkan multitafsir dan perbedaan pandangan hukum antar institusi-institusi penegak hukum baik Kepolisian, Kejaksaan maupun Badan Penyelesaian Sengketa Konsumen. Beberapa faktor pemicu perbedaan tersebut antara lain disebabkan karena perbedaan pandang mengenai penarikan kendaraan oleh debt collector, sebagian mengatakan tindakan ini sah karena didasarkan pada perjanjian pokok yaitu perjanjian pembiayaan. Namun, sebagian lain mengganggap tidak sah secara hukum karena tidak mempunyai sertifikat fidusia. Untuk menyikapi permasalahan tersebut, sebetulnya Kementerian Keuangan mengeluarkan suatu kebijakan baru Peraturan Menteri Keuangan No. 130/PMK.010/2012 tentang Pendaftaran Jaminan Fidusia Bagi Perusahaan Pembiayaan yang Melakukan Pembiayaan Konsumen untuk Kendaraan Bermotor dengan Pembebanan Jaminan Fidusia. Namun sangat disayangkan, peraturan tersebut belum disosialisakan dengan baik sehingga banyak pihak yang belum mengetahui keberadaan peraturan ini. Pemberian edukasi, sosialisasi dan penegasan aturan hukum sangat diperlukan baik kepada masyarakat, lembaga pembiayaan, penegak hukum serta instansi lain yang terkait. Agar tidak menimbulkan perbedaan pandang hukum yang multitafsir, karena perbedaan pandang tersebut justru dapat dijadikan alasan debitur untuk beritikad tidak baik.

Peraturan Menteri Keuangan tersebut merupakan sesuatu yang positif karena memberikan informasi tentang keuntungan-keuntungan yang diterima lembaga pembiayaan apabila memiliki sertifikat jaminan fidusia. Beberapa manfaat yang diterima sebagaimana dimaksud dalam Pasal 7 , Pasal 8, Pasal 9, Pasal 15, Pasal 17, Pasal 20, Pasal 21, Pasal 30 dan Pasal 35 serta Pasal 36 UU Jaminan Fidusia. Peraturan ini telah berlaku sejak tanggal 7 Oktober 2012 namun pemberlakuannya kurang kondusif karena dalam penerapannya belum disosialisasikan dengan tepat. Akibatnya, masih banyak lembaga pembiayaan yang melakukan pembebanan jaminan fidusia namun tidak didaftarkan. Kelalaian ini mengakibatkan kerugian negara karena banyak Penerimaan Negara Bukan Pajak (PNBP) pendaftaran fidusia tidak dibayarkan. Hal ini disebabkan karena kewajiban pendaftaran jaminan fidusia dapat dilakukan siapa saja baik lembaga pembiayaan, masyarakat maupun notaris.

Sangat disayangkan, dalam Peraturan Menteri Keuangan tersebut tidak mengatur secara tegas dan objektif mengenai siapa yang dapat melakukan kewajiban pendaftaran jaminan fidusia. Sebagaimana diatur dalam peraturan tersebut, saat ini tidak hanya notaris saja yang dapat melakukan pendaftaran jaminan fidusia, pihak-pihak lain pun seperti lembaga pembiayaan atau masyarakat dapat mengakses pendaftaran fidusia. Menurut Penulis, hal ini dapat memberikan peluang terhadap pengabaian pendaftaran jaminan fidusia dengan pertimbangan ekonomis 
karena pendaftaran jaminan fidusia dibebani pembayaran PNBP. Untuk itu, diperlukan suatu rekonstruksi aturan mengenai penegasan kewajiban pendaftaran jaminan fidusia yang hanya dapat dilakukan oleh notaris. Ini merupakan konsekuensi dari Pasal 5 ayat (1) UU Jaminan Fidusia yang menyatakan bahwa "Pembebanan benda dengan jaminan fidusia dibuat dengan akta notaris dalam bahasa Indonesia dan merupakan akta jaminan fidusia". Sehingga ketika seorang notaris membuat akta jaminan fidusia maka sekaligus ia berkewajiban mendaftarkannya kepada Kantor Pendaftaran Jaminan Fidusia. Penegasan ini akan mencegah terjadinya pembebanan jaminan fidusia yang tidak didaftarkan.

\section{PENUTUP}

Kekuatan eksekutorial sertifikat jaminan fidusia yang sama dengan putusan pengadilan yang telah memperoleh kekuatan hukum perlu untuk dicermati. Sertifikat tersebut tidak bersifat condemnatoir, sehingga tidak dapat dipersamakan sepenuhnya dengan putusan pengadilan yang telah memperoleh kekuatan hukum tetap (non-eksekutabel). Pemegang sertifikat jaminan fidusia berkedudukan seperti seseorang yang sudah memegang putusan pengadilan yang telah mempunyai kekuatan hukum tetap. Selanjutnya, penarikan terhadap objek jaminan fidusia dapat dilakukan melalui 2 (dua) alternatif yakni dengan dasar perjanjian pembiayaan atau dengan sertifikat jaminan fidusia. Keduanya, merupakan dasar yang sah dalam pelaksanaan eksekusi jaminan fidusia. Namun demikian, pendapat tentang 'pendaftaran jaminan fidusia adalah pilihan' tidaklah dapat dibenarkan. Sebab, Pasal 11 UU Jaminan Fidusia merupakan suatu norma yang bersifat memaksa, artinya ketentuan tersebut garus dipatuhi, tidak boleh disimpangi.

Ketentuan mengenai jangka waktu penjaminan fidusia ini belum diatur secara tegas. Sehingga berdampak pada keberlakukan dari jaminan fidusia itu sendiri. Pemberian jangka waktu penjaminan ini tidak akan menimbulkan masalah jika hutang debitur dapat dilunasi sesuai dengan tenor yang telah disepakati. Namun, akan menimbulkan masalah jika debitur meminta untuk dilakukan perpanjangan tenor untuk pelunasan hutang. Perpanjangan jangka waktu pelunasan ini seharusnya disikapi dengan pembaharuan data pendaftaran jaminan fidusia secara online. Ketentuan ini belum diatur secara tegas dalam suatu peraturan. Sehingga dapat menimbulkan permasalahan baru dan merugikan pihak penerima fidusia.

Kewajiban pendaftaran jaminan fidusia pun sering menimbulkan multitafsir dan perbedaan pandangan hukum antar institusi-institusi penegak hukum baik Kepolisian, Kejaksaan maupun Badan Penyelesaian Sengketa Konsumen. Beberapa faktor pemicu perbedaan tersebut antara lain disebabkan karena perbedaan pandang mengenai penarikan kendaraan oleh debt collector, sebagian mengatakan tindakan ini sah karena didasarkan pada perjanjian pokok yaitu perjanjian pembiayaan namun, pendapat lain mengganggap tidak sah secara hukum karena tidak mempunyai sertifikat fidusia. Kementerian Keuangan mengeluarkan suatu kebijakan baru yaitu Peraturan Menteri 
Keuangan No. 130/PMK.010/2012 untuk menyikapi perbedaan pandang tersebut. Pemberian edukasi, sosialisasi dan penegasan aturan hukum sangat diperlukan baik kepada masyarakat, lembaga pembiayaan, penegak hukum serta instansi lain yang terkait. Agar tidak menimbulkan perbedaan pandang hukum yang multitafsir.

Kewajiban pendaftaran jaminan fidusia sampai saat ini tidak hanya dapat dilakukan oleh notaris saja, melainkan dapat dilakukan oleh lembaga pembiayaan maupun masyarakat. Hal ini dapat memberikan peluang terhadap pengabaian pendaftaran jaminan fidusia. Peluang ini harus segera disikapi dengan rekonstruksi aturan tentang penegasan bahwa notarislah sebagai satusatunya pihak yang dapat mengakses / mendaftarkan jaminan fidusia sebagai konsekuensi dari ketentuan Pasal 5 ayat (1) UU Jaminan Fidusia.

\section{DAFTAR BACAAN}

\section{Buku}

Harahap M. Y, Ruang Lingkup Permasalahan Eksekusi Bidang Perdata (Cet. ke-3, Gramedia 1988).

Isnaeni Moch, Hipotek Pesawat Udara di Indonesia (Cet. pertama, CV. Dharma Muda 1996).

Kamelo T, Hukum Jaminan Fidusia Suatu Kebutuhan Yang Didambakan (Cet. pertama, Alumni 2014).

Latuihamallo Abednego I, Dilema Dunia Multifinance, Sebuah Analisis Ilmiah Terhadap Fidusia Dan Permasalahannya Dalam Dunia Multifinance (Cet. pertama,
Grasindo 2014).

Marzuki Peter M, Pengantar Ilmu Hukum (Cet. pertama, Kencana Prenada Media Group 2009).

Mertokusumo S, Hukum Acara Perdata Indonesia (Cet. pertama, Liberty 1985).

Satrio J, Hukum Jaminan, Hak Jaminan Kebendaan, Hak Tanggungan (Cet. pertama, Citra Aditya Bakti 1997).

Supianto, Hukum Jaminan Fidusia, Prinsip Publisitas Pada Jaminan Fidusia (Cet. pertama, Garudhawaca 2015).

Witanto DY, Hukum Jaminan Fidusia Dalam Perjanjian Pembiayaan Konsumen (Aspek Perikatan, Pendaftaran, Dan Eksekusi) (Cet. pertama, Mandar Maju 2015).

\section{Artikel Jurnal}

Fathoni R, Badriyah SM dan Suharto R, 'Efektivitas Pemberlakuan Pendaftaran Jaminan Fidusia Secara Elektronik Terhadap Pembiayaan Bank Syariah (Studi Pada Bank Pembiayaan Rakyat Syariah Artha Amanah Ummat Kabupaten Semarang)' (2016) 5 (3) Diponegoro Law Journal.

Pararang F, 'Implementasi Jaminan Fidusia Dalam Pemberian Kredit Di Indonesia' (2014) 1 (2) Jurnal LPPM Bidang Ekososbudkum.

Putra W dan Widjaja H, 'Penerapan Prinsip Kehati-Hatian Dalam Penyaluran Kredit (Studi Kasus di Bank BRI Cabang Semarang)' (2019) 3 (1) Refleksi Hukum: Jurnal Ilmu Hukum.

Safira Martha E, 'Analisis Perjanjian Jaminan Fidusia Terhadap Parate Eksekusi dan Perlindungan 
Hukumnya Bagi Kreditur (Studi Kasus Pada BMT dan BPR Syariah di Ponorogo)' (2014) 11 (1) Justicia Islamica.

Tanuwidjaya Tan H, 'Parate Eksekusi Hak Tanggungan Kontra Fiat Pengadilan' (2016) 10 (1) Refleksi Hukum: Jurnal Ilmu Hukum.

\section{Tesis/Disertasi}

Rufaida Khifni K, 'Keotentikan Akta Jaminan Fidusia Yang Tidak Ditandatangani Di Hadapan Notaris Setelah Berlakunya Sistim Pendaftaran Fidusia Secara Online' (Tesis, Universitas Diponegoro 2014).

\section{Putusan Pengadilan}

Sejahtera Bank Umum v Lo Tjin Kuang dan Lo Ah Lian, No. 80/Pdt.G/ 1992/PN-PMs, Pengadilan Negeri Siantar, 2 Februari 1993.

Sejahtera Bank Umum v Chairul Azhari Siregar, No. 105/Pdt.G/ 1994/PN-Mdn, Pengadilan Negeri Medan, 30 Agustus 1994.

\section{Peraturan Perundang-Undangan}

Kitab Undang-Undang Hukum Perdata (KUH Perdata).

Herzien Inlandsch Reglement (HIR).

Undang-Undang Nomor 4 Tahun 1996 tentang Hak Tanggungan.

Undang-Undang Nomor 42 Tahun 1999 tentang Jaminan Fidusia.

Peraturan Pemerintah Nomor 9 Tahun 2009 tentang Lembaga Pembiayaan.

Peraturan Pemerintah Nomor 86 Tahun 2000 tentang Tata Cara Pendaftaran Jaminan Fidusia dan
Biaya Pembuatan Akta Jaminan Fidusia.

Peraturan Menteri Keuangan Nomor 130/PMK.010/2012 tentang Pendaftaran Jaminan Fidusia bagi Perusahaan Pembiayaan.

Surat Edaran Badan Urusan Piutang dan Lelang Negara (BUPLN) Nomor SE-21/PN/1998 jo. SE23/PN/2000. 